\title{
Akut Göğüs Ağrısının Alışılmadık Bir Nedeni: Öksürüğe Bağıı Kosta Ve Skapula Kırığı
}

\section{An Unusual Cause of Acute Chest Pain: Rib and Scapula Fracture Due to Cough}

\author{
Hale Ateş
}

Öksürük hastaların tıbbi yardım gereksinimi duydukları en sık semptomlardan biridir. Kronik öksürük sıklıkla sekel bırakmadan iyileşirken nadiren pnomotoraks ve kemik fraktürleri ile sonuçlanabilir. Kostalarda daha sık olmak üzere nadiren başka anatomik lokalizasyonlarda da fraktürler meydana gelebilir. Bu olgu sunumunda literatürde nadir karşılaştığımız akut başlangıçlı göğüs ağrısı ile başvuran kronik öksürüğe bağlı sol sekizinci kosta ve sol skapulada fraktür saptanan bir vaka tartışılacaktır.

Anahtar Kelimeler: akut göğüs ağrısı, kosta kırığı, osteoporoz, öksürük, skapula kırığı
Cough is a common symptom that medical assistance is needed. Chronic cough is often recovered from without sequelae and rarely results in pneumothorax and bone fractures. Fractures may occur frequently in ribs but also in other anatomic localisations. In this case report, a type of case rarely encountered in the literature, one that presented with acute onset of chest pain, chronic cough, depending on the left eighth rib and left scapula fracture is going to be discussed.

Keywords: acute chest pain, cough, osteoporosis, rib fractures, scapula fractures

Corresponding Author: Hale Ates, MD 


\section{Introduction}

Cough is one of the most common symptoms of patients that seek medical help. Patients usually recover from cough without sequelae, but serious cough sometimes leads to complications such as pneumothorax and rib fractures. ${ }^{[1]}$ Fractures often occur after repeated mechanical stress due to chronic cough. ${ }^{[2]}$ In the literature, while chronic cough induced rib fractures ${ }^{[3-5]}$ are often cited, coexistence of rib and scapular fractures ${ }^{[6]}$ is mentioned rarely. In this case report, left scapula and left eighth rib fracture presenting with acute-onset chest pain is going to be presented.

\section{Case report}

A seventy-six years old female patient was admitted to an emergency room with acute onset of left side pain and chest pain. From her story, sudden onset severe cough and chest pain were present in the left side for four weeks and were increasing. On her physical examination on admission; fever was 36.3 으, pulse was $105 / \mathrm{min}$, blood pressure was $140 / 90 \mathrm{mmHg}$, respiratory rate was $18 /$ min. In respiratory system examination, diffuse rhonchus and severe tenderness in the left lateral thorax were present, and the examination of other systems was normal. Chronic ischemic changes and sinus tachycardia were present on electrocardiography. Posterior-anterior chest $x$-ray (PA-AG) was normal, except for cardiomegaly and chronic changes.

Because of the patient's pain that was continuous and restricting her recumbency, thoracic computed tomography (CT) without contrast was performed with the preliminary diagnosis of rib fracture. In CT, fractures were observed in the left eight rib and the left scapula. The patient was referred to the orthopaedic clinic with these findings. With symptomatic approach, shoulder-arm suspension and analgesic therapy were recommended. In the etiologic investigation of fracture, total T score was found to be -3.4 in bone mineral densitometry. Alendronate sodium, calcium carbonate and vitamin D3 were given to the patient on the recommendation of the endocrinology clinic.

\section{Discussion}

In our case we discussed a patient who presented with acute onset chest and side pain after cough. Left eighth rib and scapula fracture was detected. In Benjamin D. Medoff et al.'s case, fracture in the left scapula and left femur were detected in a 48 year old patient who presented with 2.5 months ongoing chronic cough and pain in the left shoulder. ${ }^{[6]}$ TSL Vrbanic et al. has identified right eighth rib fracture after cough in premenopausal women without osteoporosis $^{[7]}$. Chien-Fu Yeh et al. presented a case in which the left seventh rib fracture was detected by CT scan in a patient with acute onset left thoracic pain after 6 weeks coughing story. ${ }^{[8]}$ Langerhans cell histiocytosis in Benjamin D. Medoff's case, and osteoporosis in TSL Vrbanic's case were detected in the aetiology of fractures. Nothing was detected in the aetiology of Yeh ChienFu's case. If we examine the case series of Viktor Hanak et al. that involved 54 participants (42 women), rib fractures after chronic cough were detected in 46 cases. Fractures were mostly seen in the left side and usually between 5 and 9 ribs and in lateral. In the aetiology of cases, in the majority, osteoporosis and osteopenia were identified. $^{[2]}$

Although our case is similar to other cases in the literature with a lot of aspects, the existence of acute onset chest pain and the 
coexistence of rib and rarely seen scapula fracture make a difference. Patients often recover from chronic cough without sequelae, although rarely pneumothorax and bone fractures may result. There are two mechanisms for explaining the formation of bone fractures resulting from cough. ${ }^{[9]}$

Strong luxury bending force applied to $1 / 3$ central part of first rib causes cracks in ribs. With the result of recurrent, strong bending forces such as chronic cough, cracks can turn to fractures. Secondly, because of the antagonistic effect of serratus anterior and external oblique muscles which are connected to the $1 / 3$ middle part of the second rib and work against each other during cough, fractures can happen. Patients often present with acute onset and localised pain. ${ }^{[8]}$ While PA-AG chest $x$-ray view has very low sensitivity, CT scan is close to $100 \%$ sensitivity ${ }^{[10]}$. In the treatment of uncomplicated fractures, a conservative approach is sufficient.

In a patient with localised acute onset of pain after chronic cough, bone fractures should be considered a possibility. After the detection of bone fracture, further screening for aetiology should be made.

\section{Referances}

1. Madison JM, Irwin RS, Cough: a worldwide problem. Otolaryngol Clin North Am 2010; 43: 1-13, vii.

2. Hanak V, Hartman TE, Ryu JH, Coughinduced rib fractures. Mayo Clin Proc 2005; 80: 879-82.

3. Begley A, Wilson DS,Shaw J, Cough fracture of the first rib. Injury 1995; 26: 565-6.

4. Jamard B, Constantin A, Cantagrel A, Mazieres $B$,Laroche $M$, Multiple rib fractures caused by coughing in a young woman without bone loss. Rev Rhum Engl Ed 1999; 66: 237-8.

5. Kawahara $\mathrm{H}$, Baba $\mathrm{H}$, Wada $\mathrm{M}$, Azuchi $M$, Ando $M$,Imura $S$, Multiple rib fractures associated with severe coughing--a case report. Int Orthop 1997; 21: 279-81.

6. Medoff BD, Abbott GF, Louissaint A, Jr., Case records of the Massachusetts General Hospital. Case 16-2010. A 48-year-old man with a cough and pain in the left shoulder. $N$ Engl J Med 2010; 362: 2013-22.

7. Vrbanic TS, Novak S, Sestan B, Tudor A, Gulan $G, A$ case of pathological rib fractures: focal osteolysis or osteoporosis? West Indian Med J 2008; 57: 178-81.

8. Yeh CF, Su SC, Cough-induced rib fracture in a young healthy man. J Formos Med Assoc 2012; 111: 179-80.

9. Daniel R, Naidu B,Khalil-Marzouk J, Cough-induced rib fracture and diaphragmatic rupture resulting in simultaneous abdominal visceral herniation into the left hemithorax and subcutaneously. Eur J Cardiothorac Surg 2008; 34: 914-5.

10. Connolly LP, Connolly SA, Rib stress fractures. Clin Nucl Med 2004; 29: 614-6. 